УДК 346.9

DOI https://doi.org/10.32849/2663-5313/2020.8.13

\title{
Вадим Коверзнев,
}

докт. юрид. наук, дочент,

стариий науковий співробітник

Інституту економіко-правових досліджень імені В. К. Мамутова

Національної академії наук України

\section{ЕФЕКТИВНІСТЬ СУДОВОГО ЗАХИСТУ ПРАВ УЧАСНИКІВ ЕКОНОМІЧНИХ ВІДНОСИН ЯК КРИТЕРІЙ ЗАБЕЗПЕЧЕННЯ ДОСТУПУ ДО ПРАВОСУДДЯ}

У статті акцентовано увагу на тому, що забезпечення рівного доступу до правосуддя є однією з основних иілей нової програми розвитку людства до 2030 року, затвердженої Резолюиією Генеральної Асамблеї Організачії Об’єднаних Націй від 25 вересня 2015 року.

Доведено, що неодмінною умовою забезпечення особі права доступу до правосуддя є спроможність суду ефективно виконувати свої повноваження, яка напряму залежить від якості національного законодавства, котре повинно забезпечувати суд дієвими інструментами протистояння можливим деструктивним діям з боку учасників судового процесу та інших осіб, які зловживають своїми прочесуальними правами, використовуючи їх з метою перешкоджання здійсненню судочинства шляхом зриву судових засідань або затягування судового розгляду справи та відтермінування в такій спосіб ухвалення правосудного рішення. Підкреслено, що якісне прочесуальне законодавство забезпечує можливість реального здійснення судом контрольних функиій за примусовим виконанням державною виконавчою службою або приватними виконавиями ухвалених ним судових рішень, що набрали законної сили.

У процесі дослідження зроблено висновки, що чинне начіональне законодавство Украӥни містить окремі недоліки, які знижують ефективність судового захисту прав учасників економічних відносин, що зумовлює потребу його удосконалення.

Обгрунтовано необхідністьзапровадженняюридичної відповідальностіза ігнорування суб'єктами владних повноважень, які у своїй діяльності застосовують норми права, висновків Верховного Суду; розширення процесуальних повноважень господарського суду у сфері здійснення судового контролю за примусовим виконанням ухвалених ним судових рішень шляхом надання суду права скасовувати рішення (постанови) державного або приватного виконавия, які визнано судом неправомірними.

Запропоновано активізувати на загальнодержавному рівні інформачійну діяльність, спрямовану на підвищення авторитету судової гілки влади України; проведення Верховним Судом узагальнення судової практики щодо притягнення до кримінальної відповідальності за умисне ухилення від виконання судового рішення або перешкоджання його виконанню з метою правильної кваліфікації цих дій правоохоронними органами та судами нижчого рівня.

Ключові слова: господарське судочинство, учасники економічних відносин, ефективний судовий захист.

Постановка проблеми. Резолюцією Генеральної Асамблеї Організації Об'єднаних Націй від 25 вересня 2015 року затверджено нову програму розвитку людства «Перетворення нашого світу: Порядок денний у сфері сталого розвитку до 2030 року» (далі - Програма), яка підлягає реалізації усіма країнами світу, що прагнуть розвиватися на засадах співробітництва і партнерства. Програма складається із 17 цілей, спрямованих на подолання бідності, побудову миролюбного та справедливого суспільства, подальшу реалізацію прав людини, досягнення гендерної рівності.
Серед запланованих цілей Програми $€$ забезпечення рівного доступу до правосуддя, що грунтується на повазі прав людини, верховенстві права і належному врядуванні на всіх рівнях, а також на прозорих, ефективних і підзвітних інституціях [1]

Верховенство права як комплексна юридична категорія складається з таких базових елементів, як:

1) дотримання основоположних прав людини, закріплених у Конституції та міжнародних актах, що є частиною національного законодавства України; 
2) відповідність національних законодавчих актів принципу юридичної визначеності та основоположним правам, закріпленим у Конституції України та міжнародно-правових актах;

3) забезпечення кожному права на незалежний, неупереджений i справедливий суд, реальне виконання ухвалених судових рішень [2, с. 250].

Неодмінною умовою забезпечення особі права доступу до правосуддя є спроможність суду ефективно виконувати свої повноваження, що напряму залежить від якості національного законодавства, яке повинно надавати суду інструменти протистояння деструктивним діям учасників судового процесу, які зловживають своїми процесуальними правами, використовуючи їх з метою затягування розгляду справи, перешкоджають здійсненню судочинства та ухваленню правосудного рішення, а також забезпечувати здійснення судом контрольних функцій за виконанням рішення, що набрало законної сили.

Як випливає 3 офіційних статистичних даних про роботу органів державної виконавчої служби та приватних виконавців [3], протягом 2018 року на примусовому виконанні в органах державної виконавчої служби та у приватних виконавців усього перебувало 3409043 виконавчих документа. 3 них: фактично виконано 907120 виконавчих документів (26,6 \% від загальної кількості документів, що перебували на виконанні); повернуто через неможливість примусового виконання 1158689 виконавчих документів (33,98 \% від загальної кількості документів); решта виконавчих документів перебували на примусовому виконанні.

Зазначене свідчить про те, що фактичне виконання судових рішень в Україні перебуває на доволі низькому рівні, що значно знижує ефективність судового захисту прав особи та потребує вжиття дієвих заходів, спрямованих на покращення ситуації в цій сфері.

Аналіз останніх досліджень і публікацій. Наукове дослідження аспектів, що впливають на ефективність судового захисту прав учасників економічних відносин, наразі залишається поза увагою представників школи господарського права, що зумовлюе актуальність вибраної теми.

Метою статті $є$ аналіз чинного законодавства України з метою виявлення недоліків правового регулювання доступу до правосуддя, а також напрацювання пропозицій, спрямованих на покращення ефективності судового захисту прав учасників економічних відносин.

Виклад основного матеріалу. Законом України від 03.10.2017 № 2147-VIII викла- дено нову редакцію Господарського процесуального кодексу України (далі - ГПК), що діє з 15.12.2017 і визначає юрисдикцію та повноваження господарських судів [4].

Однією з основних засад господарського судочинства, визначених статтею 2 ГПК, $€$ неприпустимість зловживання процесуальними правами та обов'язковість судового рішення.

Слід зазначити, що обов'язковість судового рішення гарантована статтею $129 \mathrm{KoH}^{-}$ ституції України [5] як одна з основних засад судочинства.

Принцип обов'язковості судових рішень, що набрали законної сили, полягає в тому, що всі органи державної влади, органи місцевого самоврядування, їх посадові та службові особи, а також фізичні і юридичні особи та їх об'єднання на всій території України зобов'язані виконувати судові рішення, які стосуються прав і обов'язків зазначених осіб; цей принцип поширюється виключно на тих осіб, яких залучено судом до участі в справі.

У разі, якщо судовим рішенням вирішено питання про права, інтереси та обов'язки осіб, які не були залучені до участі в справі в якості сторони, такі особи мають право апеляційного оскарження судового рішення. Подання такою особою апеляційної скарги є безумовною підставою для скасування апеляційним судом судового рішення місцевого суду (ст. 277 ГПК).

Частиною п'ятою статті 13 Закону України «Про судоустрій і статус суддів» запроваджено інститут обов'язковості висновків Верховного Суду для суб'єктів владних повноважень, які застосовують у своїй діяльності нормативно-правовий акт, що містить відповідну норму права [6].

Вказаний інститут не пов'язаний 3 обов'язковою участю особи в справі, а поширює свою дію на невизначене коло суб'єктів владних повноважень, які здійснюють нормозастосовну діяльність.

На жаль, закріплений у Конституції та законах України принцип обов'язковості судових рішень на практиці виявив свою недієвість, оскільки, як показує статистика, стан виконання судових рішень в Україні залишається критично низьким.

Вказане пояснюється не лише скрутним фінансовим становищем, в якому нині перебувають більшість учасників економічних відносин, та їхньою нездатністю виконувати зобов'язання, а й банальним небажанням боржників виконувати судове рішення та недостатністю наявних механізмів примусу та контролю за виконанням судових рішень.

Зокрема, частиною другою статті 18 ГПК України передбачено, що невиконання судо- 
вого рішення є підставою для відповідальності, встановленої законом. Наведена норма має банкетний характер і відсилає до застосування іншого закону.

Водночас статтею 382 Кримінального кодексу України встановлено, що умисне невиконання вироку, рішення, ухвали, постанови суду, що набрали законної сили, або перешкоджання їх виконанню - карається штрафом від п'ятисот до однієї тисячі неоподатковуваних мінімумів доходів громадян або позбавленням волі на строк до трьох років; ті самі дії, вчинені службовою особою, - караються штрафом від семисот п'ятдесяти до однієї тисячі неоподатковуваних мінімумів доходів громадян або позбавленням волі на строк до п'яти років, з позбавленням права обіймати певні посади чи займатися певною діяльністю на строк до трьох років; дії, передбачені частиною першою або другою цієї статті, вчинені службовою особою, яка займає відповідальне чи особливо відповідальне становище, або особою, раніше судимою за злочин, передбачений цією статтею, або якщо вони заподіяли істотну шкоду охоронюваним законом правам і свободам громадян, державним чи громадським інтересам або інтересам юридичних осіб, - караються позбавленням волі на строк від трьох до восьми років 3 позбавленням права обіймати певні посади або займатися певною діяльністю на строк до трьох років

Хоча в Україні й запроваджено механізм притягнення до кримінальної відповідальності осіб, які умисно ухиляються від виконання судових рішень або перешкоджають виконанню судових рішень, проте кількість обвинувальних вироків за статтею 382 КК України є незначною.

Вказане пов'язано як із складністю доведення в суді умислу особи на ухилення від виконання судового рішення або умислу на перешкоджання виконанню судового рішення, так і низькою кваліфікацію співробітників правоохоронних органів, які виявляють неспроможність зібрати належні та переконливі докази вини особи у вчиненні вказаного кримінального правопорушення.

Негативний вплив має й безпідставна критика в засобах масової інформації діяльності судів України та необгрунтоване звинувачення їх у винесенні неправосудних рішень, що лунає від найвищих посадових осіб держави, що принижує авторитет судової гілки влади та утверджує переконання в можливості невиконання судових рішень.

Покращення ситуації в цій сфері можливо виключно шляхом незаангажованого висвітлення діяльності судової гілки влади та вжиття заходів щодо підвищення її авторитету серед населення України.
Крім того, існує потреба в проведенні Верховним Судом узагальнення практики притягнення осіб до кримінальної відповідальності за умисне ухилення від виконання судового рішення або перешкоджання виконанню судового рішення для того, щоб правоохоронні органи та суди мали чітке розуміння того, що вважається умисним ухиленням від виконання судового рішення та перешкоджанням виконанню судового рішення, при цьому правильно кваліфікували такі дії.

Проголошуючи обов'язковість висновків Верховного Суду для суб'єктів владних повноважень, які застосовують у своїй діяльності нормативно-правовий акт, що містить відповідну норму права, законодавець не передбачив правових наслідків порушення вказаного припису статті 13 Закону України «Про судоустрій і статус суддів», у зв'язку 3 цим особи, які наділені владними повноваженнями та застосовують у своїй діяльності норми права, часто ігнорують правові висновки Верховного Суду і тлумачать чинне законодавство на власний розсуд.

3 метою спонукання суб'єктів владних повноважень, які застосовують у своїй діяльності нормативно-правовий акт, дотримуватися висновків Верховного Суду необхідно запровадити для таких осіб адміністративну відповідальність за недотримання правових висновків і кримінальну відповідальність у тих випадках, коли такими діями заподіяно істотну шкоду правам і свободам громадян, державним чи громадським інтересам або інтересам юридичних осіб.

Статтею 135 ГПК передбачена можливість накладення на учасника справи та/або його представника штрафу за невиконання процесуальних обов'язків, покладених на цих осіб судом, а також за зловживання процесуальними правами та вчинення дій або допущення бездіяльності з метою перешкоджання судочинству. Штраф накладається ухвалою суду (ч.2 ст. 131) і становить від одного до десяти розмірів прожиткового мінімуму для працездатних осіб (ч. 1 ст. 135); у разі систематичного невиконання процесуальних обов'язків, повторного чи систематичного зловживання процесуальними правами сума штрафу, що має право накласти суд, збільшується і становить від п'яти до п’ятдесяти розмірів прожиткового мінімуму для працездатних осіб.

Передбачені в чинному ГПК заходи процесуального примусу, що може застосувати суд до осіб, які не виконують процесуальні обов'язки та зловживають процесуальними правами, видаються достатніми і такими, що забезпечують адекватну протидію судом цим порушенням. 
Особливе значення в контексті забезпечення ефективності правосуддя має механізм контролю господарського суду за примусовим виконанням ухвалених ним судових рішень, що здійснюється органами державної виконавчої служби та приватними виконавцями.

Так, згідно зі статтею 339 ГПК сторони виконавчого провадження мають право звернутися до господарського суду зі скаргою, якщо вважають, що рішенням, дією або бездіяльністю державного виконавця чи іншої посадової особи органу державної виконавчої служби або приватного виконавця під час виконання судового рішення порушено їхні права.

За приписом частини другої статті 343 ГПК у разі встановлення обгрунтованості скарги суд визнає оскаржувані рішення, дії чи бездіяльність неправомірними і зобов'язує державного виконавця або іншу посадову особу державної виконавчої служби, приватного виконавця усунути порушення (поновити порушене право заявника). Таким чином, наведена норма ГПК надає господарському суду право постановити за результатами розгляду скарги на дії або бездіяльність державного виконавця чи іншої посадової особи органу державної виконавчої служби або приватного виконавця судове рішення виключно зобов'язального характеру, яке лише зобов'язуе суб'єкта оскарження вчинити певні дії з метою поновлення порушених прав заявника.

На практиці трапляються випадки, коли господарський суд визнає оскаржувану учасником виконавчого провадження постанову державного виконавця або приватного виконавця неправомірною та зобов'язуе усунути порушення прав учасника виконавчого провадження, але державний (приватний) виконавець ухиляється від вчинення дій щодо скасування визнаної судом незаконною постанови (наприклад, постанови про закінчення виконавчого провадження через неможливість виконання виконавчого документа без участі боржника), у зв'язку 3 цим фактичне відновлення прав учасника виконавчого провадження не відбувається, а судове рішення залишається невиконаним.

Тому доцільно змінити норму частини другої статті 343 ГПК, надавши господарському суду право не лише визнавати неправомірним, але й скасовувати рішення (постанови) державного або приватного виконавця, які визнано судом неправомірними.

\section{Висновки}

Проведене дослідження дозволяє дійти висновку, що чинне законодавство України містить окремі недоліки, які знижують ефективність судового захисту прав учасників економічних відносин, що зумовлює потребу його удосконалення. 3 цією метою пропонується запровадження юридичної відповідальності за ігнорування суб'єктами владних повноважень, які у своїй діяльності застосовують норми права, висновків Верховного Суду, а також розширення процесуальних повноважень господарського суду у сфері здійснення судового контролю за виконанням ухвалених ним судових рішень.

Крім того, доцільно активізувати на загальнодержавному рівні інформаційну діяльність, спрямовану на підвищення авторитету судової гілки влади України; здійснювати узагальнення Верховним Судом судової практики щодо притягнення до кримінальної відповідальності за умисне ухилення від виконання судового рішення або перешкоджання його виконанню з метою правильної кваліфікації цих дій правоохоронними органами та судами нижчого рівня.

\section{Список використаних джерел:}

1. Перетворення нашого світу: Порядок денний у сфері сталого розвитку до 2030 року : Резолюція Генеральної Асамблеї Організації Об'єднаних Націй від 25.09 2015. URL: http://sdg.org.ua/ ua/resources-2/344-2030-2015 (дата звернення: 09.03.2020)

2. Господарське законодавство України: перспективи модернізації на засадах сталого розвитку : монографія / під заг. ред. В. А. Устименка. Київ : НАН України, Інститут економіко-правових досліджень, 2019. 320 с.

3. Звіт про роботу органів та осіб, які здійснюють примусове виконання судових рішень і рішень інших органів, про стан виконання судових рішень і рішень інших органів (крім рішень про стягнення періодичних платежів) у 2018 році : форма № 1, затверджена наказом Міністерства юстиції України від 23.06.2018 № 1979/5. URL: http://www.ae.org.ua/wp-content/uploads/2019/ 03/ae.org_ua-\% D 0 \% B 7 \% D 0 \% B 2\% D 1\% 9 6\% $1 \% 82-2018$. pdf. (дата звернення: 09.03.2020).

4. Про внесення змін до Господарського процесуального кодексу України, Цивільного процесуального кодексу України, Кодексу адміністративного судочинства України та інших законодавчих актів: Закон України від 03.10.2017 № 2147-VIII. Відомості Верховної Ради України. 2017. № 48. Ст. 436.

5. Конституція України : прийнята на п'ятій сесії Верховної Ради України 28 червня 1996 р. (зі змін. та допов.). Відомості Верховної Ради України. 1996. № 30. Ст. 141.

6. Про судоустрій і статус суддів : Закон України від 02.06.2016 № 1402-III. Відомості Верховної Ради України. 2016. № 31. Ст. 545.

7. Кримінальний кодекс України : Закон України від 05.04.2001 № 2341-III (зі змін. та доповн.). Відомості Верховної Ради України. № 25-26. Ст. 131. 
Vadym Koverznev. Effectiveness of judicial protection of the rights of participants in economic relations as a criterion for ensuring access to justice

The article emphasizes that ensuring equal access to justice is one of the main goals of the new program of human development until 2030, approved by the Resolution of the United Nations General Assembly of September 25, 2015.

It is proved that a prerequisite for ensuring a person's right of access to justice is the ability of the court to effectively exercise its powers, which directly depends on the quality of national law, which should provide the court with effective tools to counter possible destructive actions by litigants and others. rights, using them to prevent the administration of justice by disrupting court hearings or delaying the trial and thus postponing the adoption of a judicial decision. It is emphasized that high-quality procedural legislation provides for the possibility of real implementation by the court of control functions over the enforcement of the state executive service or private executors of court decisions adopted by it, which have entered into force.

In the course of the study, it was concluded that the current national legislation of Ukraine contains certain shortcomings that reduce the effectiveness of judicial protection of the rights of participants in economic relations, which necessitates its improvement.

The necessity of introduction of legal responsibility for ignoring by subjects of the power which in the activity apply norms of the right, conclusions of the Supreme Court is proved; expansion of procedural powers of the commercial court in the field of judicial control over the implementation of court decisions by granting the court the right to cancel decisions (resolutions) of public or private executors, which are recognized by the court as illegal.

It is proposed to intensify information activities at the national level aimed at increasing the authority of the judiciary of Ukraine; conducting by the Supreme Court of generalization of judicial practice on bringing to criminal responsibility for intentional evasion of execution of a court decision or obstruction of execution of a court, in order to properly qualify these actions by law enforcement agencies and lower courts.

Key words: commercial litigation, participants of economic relations, effective judicial protection. 